\title{
The nutritional status of women of the coastal region of the Great East Japan Earthquake disaster area: Three years after
}

\author{
Yuka Kotozaki* \\ Smart Ageing International Research Center, Institute of Development, Aging and Cancer, Tohoku University, Senday, Japan
}

\begin{abstract}
Three and a half years have passed since the Great East Japan Earthquake. The life of residents has recovered close to pre-disaster conditions. However, previous studies reported that disaster survivors occurred in the past have a low standard of nutrition among residents. The purpose of this study was to investigate the nutritional status of women in the coastal region of the disaster area three years after the Great East Japan Earthquake. The participants included 145 healthy women volunteers. Participants lived in the coastal region of the disaster area immediately after the earthquake. All participants were interviewed by trained psychologists using the Japanese version of the Clinician-Administered Posttraumatic Stress Disorder Scale (CAPS). In addition, participants answered a brief self-report dietary history questionnaire. No significant differences were found between age groups on the CAPS. Significant differences between age groups in nutritional intake were found, including in protein, vegetable protein, animal protein, fat, animal fat, calcium, iron, saturated fatty acid, total dietary fiber, and cholesterol.
\end{abstract}

\section{Introduction}

Following the 2011 Great East Japan Earthquake, many residents, in particular those of the coastal region, lived in shelters for the first few months after the earthquake [1]. Standards of living were marked by a deterioration in the quantity and quality of food intake [1]. Three and a half years have passed since the Great East Japan Earthquake, with the life of residents recovering to close to pre-earthquake conditions. However, studies investigating the experience of residents have found the nutritional status of residents to be low post-disaster.

The purpose of this study was to investigate women's nutritional status in the coastal region of the disaster area, three years after the Great East Japan Earthquake.

\section{Materials and methods}

\section{Participants}

The study participants included 145 healthy women volunteers (aged 21-68 years; mean: $47.74 \pm 8.78$ years). Participants lived in the coastal region of the disaster area immediately after the earthquake up until the time of the study. They were recruited through local newspapers notices. Participants gave written informed consent following explanation of the nature of the study. Neuropsychiatric disorders were screened for using the Mini International Neuropsychiatric Interview (MINI) [2,3]. No participants were found to have a history of neurological or psychiatric illness. All procedures were conducted according to the Declaration of Helsinki. The experimental protocol was approved by the ethics committee of the Tohoku University School of Medicine.

\section{Psychological instruments}

All participants were interviewed by trained psychologists using the Japanese version of the Clinician-Administered Post-Traumatic
Stress Disorder (PTSD) Scale (CAPS [4,5]). The CAPS is a 22-item scale with three associated features assessing validity, severity, and improvement. The CAPS contains separate 5-point frequency and intensity rating scales (0-4) for symptoms identified with PTSD in the DSM-IV. Nutritional status was evaluated using a brief self-report dietary history questionnaire containing questions about the frequency of consumption of 75 principal foods [6].

\section{Analysis of psychological instruments}

Data obtained from the psychological instruments were analyzed using SPSS (Version 21.0, IBM, Armonk, New York). Physical status was compared across age groups using Tukey's multiple comparison test after analysis of variance (ANOVA). Differences in nutrient and food intake between age groups were analyzed using an item-by-item one-way ANOVA. Statistical significance was assessed according to a probability of $\mathrm{p}<0.05$.

\section{Results}

The age groups of participants are shown in Table 1. The number of participants in their 20s and 60s was relatively low; while the number of participants in their 40 s was high. Table 2 shows the CAPS score for each age group. The CAPS score for those in their 60s was higher compared to other age groups. However, the CAPS score was considered low for

Correspondence to: Yuka Kotozaki, Smart Ageing International Research Center, Institute of Development, Aging and Cancer, Tohoku University, Seiryo-machi 4-1, Aoba-ku, Sendai 980-8575;E-mail: kotoyuka@idac.tohoku.ac.jp

Key words: great east japan earthquake, post-quake; post-disaster, women's health, nutritional sta

Received: January 24, 2015; Accepted: January 30, 2015; Published: February 02,2015 
Table 1. Age groups of participants.

\begin{tabular}{|c|c|c|}
\hline & Number of people & $\mathbf{\%}$ \\
\hline $20 \mathrm{~s}$ & 6 & 4.1 \\
\hline $30 \mathrm{~s}$ & 17 & 11.7 \\
\hline $40 \mathrm{~s}$ & 62 & 42.8 \\
\hline $50 \mathrm{~s}$ & 55 & 37.9 \\
\hline $60 \mathrm{~s}$ & 5 & 3.4 \\
\hline Total & 145 & 100 \\
\hline
\end{tabular}

Table 2. CAPS score by age group.

\begin{tabular}{|c|c|}
\hline & CAPS score \\
\hline $20 \mathrm{~s}$ & $3.00 \pm 4.69$ \\
\hline $30 \mathrm{~s}$ & $1.00 \pm 3.43$ \\
\hline $40 \mathrm{~s}$ & $2.39 \pm 5.57$ \\
\hline $50 \mathrm{~s}$ & $1.91 \pm 4.04$ \\
\hline $60 \mathrm{~s}$ & $7.40 \pm 4.88$ \\
\hline
\end{tabular}

Table 3. Height, weight and BMI by age group.

\begin{tabular}{|c|c|c|c|}
\hline & Height & Weight & BMI \\
\hline $20 \mathrm{~s}$ & $154.03 \pm 3.48$ & $49.62 \pm 8.17$ & $20.86 \pm 2.97$ \\
\hline $30 \mathrm{~s}$ & $157.15 \pm 5.12$ & $56.85 \pm 9.06$ & $23.04 \pm 3.60$ \\
\hline $40 \mathrm{~s}$ & $158.00 \pm 4.74$ & $58.04 \pm 8.16$ & $23.28 \pm 3.36$ \\
\hline $50 \mathrm{~s}$ & $156.72 \pm 5.39$ & $55.26 \pm 9.14$ & $22.49 \pm 3.47$ \\
\hline $60 \mathrm{~s}$ & $152.12 \pm 3.23$ & $52.40 \pm 6.65$ & $22.65 \pm 2.79$ \\
\hline
\end{tabular}

Table 4. Nutrient and food intake by age group.

\begin{tabular}{|c|c|c|c|c|}
\hline & Protein (g/day) & $\begin{array}{c}\text { Animal protein } \\
(\mathrm{g} / \mathrm{day})\end{array}$ & $\begin{array}{c}\text { Vegetable protein } \\
\text { (g/day) }\end{array}$ & $\begin{array}{c}\text { Fat } \\
(\mathrm{g} / \text { day })\end{array}$ \\
\hline $20 \mathrm{~s}$ & $54.42 \pm 18.90$ & $30.58 \pm 16.11$ & $23.84 \pm 7.36$ & $46.27 \pm 18.32$ \\
\hline $30 \mathrm{~s}$ & $55.03 \pm 15.50$ & $27.79 \pm 9.15$ & $27.24 \pm 9.70$ & $43.28 \pm 14.57$ \\
\hline $40 \mathrm{~s}$ & $77.89 \pm 28.79$ & $43.27 \pm 21.22$ & $34.62 \pm 14.49$ & $60.13 \pm 20.75$ \\
\hline $50 \mathrm{~s}$ & $75.18 \pm 26.57$ & $42.74 \pm 21.20$ & $32.44 \pm 8.88$ & $53.50 \pm 19.24$ \\
\hline \multirow[t]{2}{*}{$60 \mathrm{~s}$} & $75.16 \pm 31.81$ & $36.58 \pm 21.20$ & $38.58 \pm 12.02$ & $53.71 \pm 29.82$ \\
\hline & $\begin{array}{c}\text { Animal fat } \\
\text { (g/day) }\end{array}$ & $\begin{array}{c}\text { Carbohydrate } \\
\text { (g/day) }\end{array}$ & $\begin{array}{l}\text { Sodium } \\
\text { (mg/day) }\end{array}$ & $\begin{array}{l}\text { Calcium } \\
\text { (mg/day) }\end{array}$ \\
\hline $20 \mathrm{~s}$ & $22.04 \pm 11.15$ & $204.97 \pm 59.07$ & $3273.16 \pm 1539.03$ & $347.58 \pm 172.25$ \\
\hline $30 \mathrm{~s}$ & $18.03 \pm 6.46$ & $221.60 \pm 71.41$ & $3746.98 \pm 1003.25$ & $365.48 \pm 155.53$ \\
\hline $40 \mathrm{~s}$ & $28.05 \pm 10.59$ & $266.90 \pm 92.11$ & $4488.74 \pm 1448.89$ & $593.03 \pm 236.73$ \\
\hline $50 \mathrm{~s}$ & $25.20 \pm 11.79$ & $239.45 \pm 64.42$ & $4272.93 \pm 1449.96$ & $610.17 \pm 192.80$ \\
\hline \multirow[t]{2}{*}{$60 \mathrm{~s}$} & $22.87 \pm 17.28$ & $258.46 \pm 60.55$ & $4497.70 \pm 1696.55$ & $674.33 \pm 307.84$ \\
\hline & $\begin{array}{c}\text { Iron } \\
\text { (mg/day) }\end{array}$ & $\begin{array}{c}\omega-3 \text { fatty acid } \\
\text { (g/day) }\end{array}$ & $\begin{array}{l}\omega-6 \text { fatty acid } \\
\text { (g/day) }\end{array}$ & $\begin{array}{c}\text { Saturated fatty } \\
\text { acid (g/day) }\end{array}$ \\
\hline $20 \mathrm{~s}$ & $5.92 \pm 2.13$ & $2.06 \pm 1.23$ & $9.24 \pm 4.23$ & $12.34 \pm 4.90$ \\
\hline $30 \mathrm{~s}$ & $6.47 \pm 2.46$ & $2.09 \pm 0.75$ & $9.12 \pm 3.14$ & $11.00 \pm 3.96$ \\
\hline $40 \mathrm{~s}$ & $8.90 \pm 3.69$ & $2.82 \pm 1.27$ & $11.40 \pm 4.55$ & $16.84 \pm 5.49$ \\
\hline $50 \mathrm{~s}$ & $8.78 \pm 2.71$ & $2.93 \pm 1.31$ & $10.29 \pm 3.48$ & $14.45 \pm 5.36$ \\
\hline \multirow[t]{2}{*}{$60 \mathrm{~s}$} & $10.90 \pm 3.31$ & $2.91 \pm 1.87$ & $10.68 \pm 6.39$ & $13.61 \pm 73.68$ \\
\hline & $\begin{array}{l}\text { Salt equivalent } \\
\text { (g/day) }\end{array}$ & $\begin{array}{c}\text { Total dietary fiber } \\
\text { (g/day) }\end{array}$ & $\begin{array}{l}\text { Alcohol } \\
\text { (g/day) }\end{array}$ & $\begin{array}{c}\text { Cholesterol } \\
\text { (mg/day) }\end{array}$ \\
\hline $20 \mathrm{~s}$ & $8.27 \pm 3.91$ & $9.12 \pm 3.71$ & $0.00 \pm 0.00$ & $300.25 \pm 141.85$ \\
\hline $30 \mathrm{~s}$ & $9.45 \pm 2.52$ & $10.66 \pm 4.64$ & $6.65 \pm 10.27$ & $264.84 \pm 102.08$ \\
\hline $40 \mathrm{~s}$ & $11.33 \pm 3.66$ & $14.17 \pm 5.89$ & $5.74 \pm 10.93$ & $405.02 \pm 168.44$ \\
\hline $50 \mathrm{~s}$ & $10.78 \pm 3.66$ & $14.47 \pm 4.47$ & $7.85 \pm 15.55$ & $375.78 \pm 167.87$ \\
\hline $60 \mathrm{~s}$ & $11.34 \pm 4.28$ & $19.45 \pm 6.48$ & $0.11 \pm 0.25$ & $418.64 \pm 202.06$ \\
\hline
\end{tabular}

all age groups. Furthermore, there were no significant differences in CAPS scores between age groups (CAPS score: p0.117). Table 3 shows the physical status for each age group. Examination of average height and weight showed no large differences between age groups. Average body mass index (BMI) was within the normal healthy range (BMI18.5 to $24.9 \mathrm{~kg} / \mathrm{m}^{2}$ ) for all age groups. For height, weight, and BMI, no significant differences were found between age groups (height: p0.052, weight: p0.096, BMI: p0.445).

Table 4 shows nutrient and food (protein, vegetable protein, animal protein, fat, animal fat, carbohydrate, sodium, calcium, iron, $\omega-3$ fatty acid, $\omega-6$ fatty acid, saturated fatty acid, salt equivalent, total dietary fiber, alcohol, and cholesterol) intake for each age group. Intake of the following items differed significantly between age groups: protein $(\mathrm{F}(4,140) 3.32, \mathrm{p}<.05)$, vegetable protein $(\mathrm{F}(4,140) 2.49, \mathrm{p}<.05)$, animal protein $(\mathrm{F}(4,140) 3.07, \mathrm{p}<.05)$, fat $(\mathrm{F}(4,140) 2.90$, $\mathrm{p}<.05)$, animal fat $(\mathrm{F}(4$, $140) 3.04, \mathrm{p}<.05)$, calcium $(\mathrm{F}(4,140) 6.52, \mathrm{p}<.01)$, iron $(\mathrm{F}(4,140) 3.75$, $\mathrm{p}<.01)$, saturated fatty acid $(\mathrm{F}(4,140) 4.82, \mathrm{p}<.01)$, total dietary fiber $(\mathrm{F}(4,140) 4.54, \mathrm{p}<.01)$, and cholesterol $(\mathrm{F}(4,140) 2.90, \mathrm{p}<.05)$.

Protein intake significantly differed between the 30 s and 40 s groups (p.017). Animal protein intake was significantly different between the 30s and 40s (p.021) and the 30s and 50s (p.032) groups. Fat intake was significantly different between the 30s and 40s (p.019) groups. Animal fat intake was significantly different between the 30s and 40s (p.009) groups. Calcium intake was significantly different between the $20 \mathrm{~s}$ and 50s (p.038), 30s and 40s (p.001), 30s and 50s (p.001), 30s and 60s (p.039) groups. Iron intake was significantly different between the $30 \mathrm{~s}$ and $40 \mathrm{~s}$ (p.048) groups. Saturated fatty acid intake differed significantly between the $30 \mathrm{~s}$ and $40 \mathrm{~s}$ (p.001) groups, while total dietary fiber intake significantly differed between the $20 \mathrm{~s}$ and $60 \mathrm{~s}$ (p.011) and 30s and 60s (p.010) groups. Finally, cholesterol intake significantly differed between the 30s and 40s (p.016) groups.

\section{Discussion}

The present study sought to measure the nutritional status of women living in the coastal region of the Great East Japan Earthquake disaster area. The CAPS score, as a measure of PTSD, was higher for the 60s age group compared to the other age groups. However, the CAPS scores were low for all age groups, with no subjects assessed as having PTSD. There were no significant differences between age groups on the CAPS. Nutrient and food intake of protein, vegetable protein, animal protein, fat, animal fat, calcium, iron, saturated fatty acid, total dietary fiber, and cholesterol was significantly different between generations.

Although PTSD symptoms decrease over time (from the time of exposure to trauma), symptoms have been shown to persist over long periods $[7,8]$. In the current study, the CAPS scores of participants were between 0 and less than 20. This result supports the spontaneous (that is, the absence of any kind of intervention) recovery of participants over the three years following the earthquake.

With regard to nutrient and food intake, most were lower for participants in their 20s compared to the other age groups (e.g., protein, calcium, iron, and total dietary fiber). Additionally, nutrient and food intake of participants in their 40s and 60s was higher than the intake of those of other age groups, depending on the nutrient (e.g., the 40s had higher protein, animal protein, fat, animal fat, carbohydrate, $\omega-6$ fatty acid, and saturated fatty acid intake; the 60 s had higher vegetable protein, sodium, calcium, iron, salt equivalent, total dietary fiber, and cholesterol intake).

In the following paragraphs, we will discuss protein, calcium, and iron in relation to national averages. The average protein intake of iron for participants in their 20s and 30s was less than Japan's average intake [9] 20s: $67.2 \pm 23.5 \mathrm{mg}$; 30s: $66.8 \pm 21.8 \mathrm{mg}$ ). Protein is one of the most important components of the human body. When protein is broken down, glucose is produced. When protein intake is insufficient, and stress hormones are continually produced over the long term, the 
internal protein resolution is enhanced and invites a drop in immunity. Adequate levels of intake must take into account the maintenance of immunity proteins and the necessary compensation due to stress [10]. Previous studies have documented the insufficient protein levels of young women in Japan [11-14]. Although this finding may not be a direct result of the earthquake, it can be said to support the conventional findings mentioned above that were talked about originally.

Calcium plays an important role in the brain. The passing of the electrical signal from neurons to cells occurs through voltage-dependent calcium ion channels, present in the cell membrane nerve cells. Once the electrical signal produced by the cations has flowed through the channels, neurotransmitters, such as acetylcholine and noradrenaline, are released from synaptic vesicles [15]. The difference in calcium intake for participants in their 20s and 60s was about 2-fold (20s: 347.58 $\pm 172.25 \mathrm{mg}$; $60 \mathrm{~s}$ : $674.33 \pm 307.84 \mathrm{mg}$ ). Looking at historical data on calcium intake, the calcium intake of young people has decreased [9]. One of the key explanations for this is considered to be the modern diet of young people, which features excessive consumption [9]. In other words, there are few calcium intakes of the youth. It should also be noted that calcium is connected with stress [16]. Applying the mental stress and physical stress, absorption rate of calcium in the intestinal tract is reduced and cortisol and noradrenaline, which is secreted in times of stress to promote the urinary excretion of calcium.

Iron is a cofactor of many enzymes that participate in the process of energy production [5]. Reduced hemoglobin concentration can lead to iron deficiency, a reduction in the oxygen-carrying capacity of the blood, a decrease in the efficiency of glucose utilization [16]. Iron is also involved in the immune system with the production of antibodies $[17,18]$. The average intake of iron for participants in their 20s, 30s, and $60 \mathrm{~s}$ was lower than the national average [9] 20s and 30s: $6.9 \pm 2.7 \mathrm{mg}$; $60 \mathrm{~s}: 8.5 \pm 3.3 \mathrm{mg}$ ). The intake of iron for all other age groups was higher than the national average (40s: $7.2 \pm 2.6 \mathrm{mg}$; $50 \mathrm{~s}: 7.8 \pm 2.8 \mathrm{mg}$ ). A study on the Sichuan Earthquake in 2008 reported iron deficiencies in infants and adult women (including pregnant women and lactating women) one year post-disaster [8]. It is difficult to make comparisons between the Sichuan Earthquake study and the current study because of the difference in time elapsed since the disaster. We consider the low levels of iron in young women to be due to factors outside of any direct effects of the earthquake. Given the three-year post-disaster period, the direct effects of the earthquake would have faded. Low levels of iron in young Japanese women may be due to slimming diets. In addition, previous studies suggest that iron-deficiency anemia is common among women of childbearing age $[11,12]$.

The current study has several limitations. First, our sample size was not large enough to sufficiently represent all age groups. In future studies, we will seek to investigate a larger number of people living in the disaster area. Second, the number of factors that we investigated was somewhat limited. Other psychological variables, including health and quality of life, were not featured in the current study and may be looked at through future research.

\section{Acknowledgment}

We thank Ms. Masumi Kanno, Mr. Misaki Chiba, and Ms. Rei Takamatsu for helping with this study. This work was supported in part by grants from the local community recovery support business in the disaster area through the authority of the Ministry of Education, Culture, Sports, Science and Technology in Japan (MEXT). The authors declare no conflicts of interest.

\section{References}

1. Kishimoto M, Noda M (2012) The Great East Japan Earthquake: experiences and suggestions for survivors with diabetes (perspective). PLoS Currents 4. [Crossref]

2. Sheehan DV, Lecrubier Y, Sheehan KH, Amorim P, Janavs J, et al (1998) The MiniInternational Neuropsychiatric Interview (M.I.N.I.): the development and validation of a structured diagnostic psychiatric interview for DSM-IV and ICD-10. J Clin Psychiatry 59 22-33.

3. Otsubo T, Tanaka K, Koda R, Shinoda J, Sano N, et al. (2005) Reliability and validity of Japanese version of the Mini-International Neuropsychiatric Interview. Psychiatry Clin Neurosci 517-26. [Crossref]

4. Blake DD, Weathers FW, Nagy LM, Kaloupek DG, Gusman FD, et al. (1995) The development of a Clinician-Administered PTSD Scale. J Trauma Stress 8: 75-90. Epub [Crossref]

5. Asukai N, Nishizono-Maher A (1998) The Japanese Version of Clinician-Administered PTSD Scale Tokyo. Tokyo Institute of Psychiatry.

6. Kobayashi S, Honda S, Murakami K, Sasaki S, Okubo H, et al. (2012) Both comprehensive and brief self-administered diet history questionnaires satisfactorily rank nutrient intakes in Japanese adults. J Epidemiol 22: 151-159. [Crossref]

7. McCarroll JE, Ursano RJ, Fullerton CS, Oates GL, Ventis WL, et al. (1995) Gruesomeness, emotional attachment, and personal threat: dimensions of the anticipated stress of body recovery. J Traum Stress 8: 343-349. [Crossref]

8. Yin SA, Dong CX (2011) The nutritional status and improving ways of reproductive women and children in the disaster areas at about one year after Wenchuan Earthquake. Vitamins 85: 97-111.

9. Ministry of Health, Labour and Welfare (2012) The National Health and Nutrition Survey in Japan. (in Japanese).

10. Sudo N, Sawaguchi M, Yoshiike N (2010) Changes in Food Intakes and Required Nutrients under Stress: to Support Disaster Victims with Food Assistance. J Jpn Dietetic Assoc 53: 349-355.

11. Uchida T, Yoshida M, Sakai K, Kokubun K, Igarashi T, et al. (1998) Prevalence of iron deficiency in Japanese women. Nippon Ketsueki Gakkai Zasshi 51: 24-27 (in Japanese). [Crossref]

12. Tsuda T, Ohya T (1998) Food Behavior of Young Women from Two Different Sized Cities in Japan. Society for Nutrition Education $31^{\text {st }}$ Annual Meeting 73.

13. Tsuda T, Ohya T (1999) Food Behavior of Female College Students from Two Different Sized Cities Tokyo and Yonezawa in Japan. $10^{\text {th }}$ Biennial Congress of ARAHE $\square$ The Japan Society of Home Economics: 256-257.

14. Ando K, Morita S, Higashi T, Fukuhara S, Watanabe S, et al. (2006) Health-related quality of life among Japanese women with iron-deficiency anemia. Qual Life Res 15 1559-1563. [Crossref]

15. Rawn JD (1989) Biochemistry. Neil Patterson Publishers, North Carolina 1057-1058.

16. Benton D, Nabb S (2003) Carbohydrate, Memory, and Mood. Nutr Rev 61: 61-67.

17. Kiple KF, Ornelas KC, eds. (2000) The Cambridge World History of Food; Cambridge University Press, Cambridge.

18. Lieberman S, Bruning N (2003) The Real Vitamin and Mineral Book, Third edition. Avery, New York 193.

Copyright: (C2015 Kotozaki Y. This is an open-access article distributed under the terms of the Creative Commons Attribution License, which permits unrestricted use, distribution, and reproduction in any medium, provided the original author and source are credited. 